\title{
Current contributions to the systematics of Thraulodes Ulmer 1920 (Ephemeroptera: Leptophlebiidae)
}

\author{
LUKE M. JACOBUS ${ }^{1}$ \\ ${ }^{1}$ Division of Science, Indiana University Purdue University Columbus, 4601 Central Avenue, Columbus, Indiana 47203, USA. \\ ”llukemjacobus@alumni.purdue.edu; † https://orcid.org/0000-0002-7201-3922
}

In a series of papers in this issue of Zootaxa, several new species of prong-gilled mayflies (Ephemeroptera: Leptophlebiidae) are described. Among them, an additional five new species are added to the genus Thraulodes Ulmer 1920, based on material from different parts of Brazil. Thraulodes is one of the more species-rich genera of Ephemeroptera worldwide, and it is one of the most abundant leptophlebiids in South America, being found in almost all streams and rivers there (Domínguez et al. 2006, Jacobus et al. 2019). It has a range of distribution that includes North, Central and South America; however, it is not known from the Antilles. A Neotropical recent center of dispersal for this Panamerican genus has been hypothesized (McCafferty 1998). Species from outside the Americas almost certainly belong to other genera or even to other families (Kluge 2004, 2020). Kluge (2020) recently published a monographic study of the group in this journal; he reported about 70 species for the genus and named 10 new ones. Cortes et al. (2021) subsequently described a new species, and Pérez-Garcia et al. (2021) provided some new records and biogeographic analysis, along with an updated list of species. In the current issue of Zootaxa, Raymundo et al. (2021) describe one new species based on imagoes, and they provide the first description of a nymph for a species and the female imago for another species; Nascimento et al. (2021) describe three species based on imagoes; and Orlando et al. (2021) describe one new species based on male imagoes. This brings the total number of valid nominal species in Thraulodes to about 86 (Kluge 2020, Cortes et al. 2021, new data).

Eighty-six is a remarkable number of species for a mayfly genus. For comparison, over half of mayfly families have fewer than 20 species each. Only five genera of mayflies have more species than Thraulodes: Baetis Leach 1815 (Baetidae), Caenis Stephens 1835 (Caenidae), Epeorus Eaton 1881 (Heptageniidae), Labiobaetis Novikova \& Kluge 1997 (Baetidae) and Rhithrogena Eaton 1881 (Heptageniidae) (Barber-James et al. 2008: Table 3, Barber-James et al. 2013, Sartori \& Brittain 2015: Table 34.2, Jacobus et al. 2019, Kaltenbach \& Gattolliat 2021, Malzacher \& Barber-James 2021). These six genera account for a little more than one in five of the valid species names of recent mayflies (Jacobus et al. 2021, unpublished data). Keep in mind, however, that Baetis and Cloeon numbers may be inflated by the fact that several species in each genus simply bear that name and have not been studied sufficiently enough to place them elsewhere in our generic classification system of mayflies; moreover, different concepts of these genera-some more or less inclusiveare utilized by different authors. Also, in my opinion, the numbers of species should be re-evaluated, because they may represent tallies that have been carried over from count to count, when the focus has been across the order, rather than on a comprehensive view of that particular genus at that moment in time, which makes it easy to overlook taxonomic changes or additions in unfamiliar publications.

As is especially the case with diverse and widespread taxa that predominately receive piecemeal attention, more work is required on Thraulodes systematics. Certainly, more species remain to be described and named, but also careful and methodical associations of metamorphic stages should be made whenever possible. These latter incremental advances will clarify species identities - especially those North \& Central American species names based only on the difficult to diagnose nymphs (e.g., Kilgore \& Allen 1973, Lugo-Ortiz \& McCafferty 1996, McCafferty et al. 2004)—and may prove to establish some junior synonyms or even move some species to other genera. Moreover, a few nominal species concepts may be conglomerate in nature. Domínguez et al. (2006) and Kluge (2020) elaborate some of these areas of concern.

Even if we discover or confirm that the morphologies of several different species of nymphs are indistinguishable from one another, the knowledge of this fact is informative to the approaches we must take to study and report on the group, and it is valuable for recognizing our limitations. Molecular methods will undoubtedly help us understand the

4 Accepted by Z.-Q. Zhang: 9 Nov. 2021; published: 7 Dec. 2021

Licensed under Creative Commons Attribution-N.C. 4.0 International https://creativecommons.org/licenses/by-nc/4.0/ 
systematics of Thraulodes and other diverse genus groups, but assigning names to phylogenetic tree terminals comes down to recognizing species at the morphological level at some point in time. Thus, we must continue to work on these groups at a very basic, descriptive level. This series of papers contributes to that forward progress.

\section{References}

Barber-James, H.M., Gattolliat, J.-L., Sartori, M. \& Hubbard, M.D. (2008) Global diversity of mayflies (Ephemeroptera, Insecta) in freshwater. Hydrobiologia, 595, 339-350. https://doi.org/10.1007/s10750-007-9028-y

Barber-James, H.M., Gattolliat, J.-L., Sartori, M. \& Webb, J. (2013) World Checklist of Freshwater Ephemeroptera Species. Available online: http://fada.biodiversity.be/group/show/35 (accessed 18 December 2013)

Cortes, I.C.H., Dias, L.G. \& Araújo, V.A. (2021) A new species of Thraulodes Ulmer (Ephemeroptera: Leptophlebiidae), with additional data on the anatomy of the reproductive tract. Revista Brasileira de Entomologia, 65 (2), e20210014. https://doi.org/10.1590/1806-9665-RBENT-2021-0014

Domínguez, E., Molineri, C., Pescador, M.L., Hubbard, M.D. \& Nieto, C. (2006) Ephemeroptera of South America. Aquatic Biodiversity in Latin America. Vol. 2. Pensoft, Sofia-Moscow, 646 pp.

Eaton, A.E. (1881) An announcement of new genera of the Ephemeridae. Entomologist's Monthly Magazine, 18, 21-27.

Jacobus, L.M., Macadam, C.R. \& Sartori, M. (2019) Mayflies (Ephemeroptera) and their contributions to ecosystem services. In: Morse, J.C. \& Adler, P.H. (Eds.), Diversity and Ecosystem Services of Aquatic Insects. Insects, 10 (6), 170. https://doi.org/10.3390/insects10060170

Jacobus, L.M., Salles, F.F., Price, B., Pereira-da-Conceicoa, L., Dominguez, E., Suter, P.J., Molineri, C., Tiunova, T. \& Sartori, M. (2021) Mayfly taxonomy (Arthropoda: Hexapoda: Ephemeroptera) during the first two decades of the twenty-first century and the concentration of taxonomic publishing. Zootaxa, 4979 (1), 25-30. https://doi.org/10.11646/zootaxa.4979.1.6

Kaltenbach, T. \& Gattolliat, J.-L. (2021) New species of Labiobaetis Novikova \& Kluge from Southeast Asia and New Guinea (Ephemeroptera, Baetidae). ZooKeys, 1067, 159-208. https://doi.org/10.3897/zookeys.1067.72251

Kilgore, J.L. \& Allen, R.K. (1973) Mayflies of the Southwest: new species, descriptions, and records (Ephemeroptera). Annals of the Entomological Society of America, 66 (2), 321-332. https://doi.org/10.1093/aesa/66.2.321

Kluge, N.J. (2004) The phylogenetic system of Ephemeroptera. Kluwer Academic Publishers, Dordrecht, 456 pp. https://doi.org/10.1007/978-94-007-0872-3

Kluge, N.J. (2020) Systematic position of Thraulodes Ulmer 1920 (Ephemeroptera: Leptophlebiidae) and descriptions of new and little-known species. Zootaxa, 4756(1), Zootaxa, 4756 (1), 1-142. https://doi.org/10.11646/zootaxa.4756.1.1

Leach, W.E. (1815) Entomology. Brewster's Edinburgh Encyclopedia, 9, 52-172.

Lugo-Ortiz, C.R. \& McCafferty, W.P. (1996) New species of Leptophlebiidae (Ephemeroptera) from Mexico and Central America. Annales de Limnologie (International Journal of Limnology), 32 (1), 3-18. https://doi.org/10.1051/limn/1996004

Malzacher, P. \& Barber-James, H.M. (2021) New Caenis species (Insecta: Ephemeroptera: Caenidae) from Angola, Okavango and Zambezi River basins. African Entomology, 29(2), 563-589. https://doi.org/10.4001/003.029.0563

McCafferty, W.P. (1998) Ephemeroptera and the great American interchange. Journal of the North American Benthological Society, 17 (1), 1-20. https://doi.org/10.2307/1468048

McCafferty, W.P., Baumgardner, D.E. \& Guenther, J.L. (2004) The Ephemeroptera of Central America. Part 1: Guatemala. Transactions of the American Entomological Society, 130 (2-3), 201-219.

Nascimento, J.M.C., Castelaci, L.C. \& Hamada, N. (2021) More about Thraulodes Ulmer, 1920 (Ephemeroptera: Leptophlebiidae) from the Brazilian Amazonia: three new species, a new record and a gynandromorph report. Zootaxa, 5076 (1), $21-38$. https://doi.org/10.11646/zootaxa.5076.1.5

Novikova, E.A. \& Kluge, N.J. (1987) Systematics of the genus Baetis (Ephemeroptera: Baetidae) with description of a new species from Middle Asia. Vestnik Zoologii, 4, 8-19.

Orlando, T.Y., Salles, F.F., Boldrini, R. \& Krolow, T.K. (2021) Updated records for Leptophlebiidae (Ephemeroptera) and a new species of Thraulodes Ulmer, 1920 from Tocantins State, Northern Brazil. Zootaxa, 5076 (1), 39-55. https://doi.org/10.11646/zootaxa.5076.1.6

Pérez-García, B., Liria, J., Leal-Sánchez, R., Nieto-Caicedo, L. \& Guerrero-Donoso, E. (2020). Thraulodes marreroi Chacón, Segnini y Domínguez (Ephemeroptera: Leptophlebiidae: Atalophlebiinae): nuevos registros para Venezuela y un análisis sobre su distribución neotropical mediante el modelo de nicho ecológico. Revista chilena de entomología, 46 (3), $509-520$. https://doi.org/10.35249/rche.46.3.20.17

Raymundo, T.D.S., Almeida, T.B., Nascimento, J.M.C. \& Salles, F.F. (2021) Thraulodes Ulmer 1920 (Ephemeroptera: Leptophlebiidae) from Espírito Santo state, Brazil. Zootaxa, 5076 (1), 7-20. 
https://doi.org/10.11646/zootaxa.5076.1.4

Sartori, M. \& Brittain, J.E. (2015) Chapter 34. Order Ephemeroptera. In: Thorp, J.H. \& Rogers, D.C. (Eds.), Ecology and general biology: Thorp and Covich's freshwater invertebrates. 3rd Edition. Academic Press, Cambridge, pp. 873-891. https://doi.org/10.1016/B978-0-12-385026-3.00034-6

Stephens, J.F. (1835) Family III.-Ephemeridae, Leach. Illustrations of British Entomology, Mandibulata, 6, 54-70.

Ulmer, G. (1920) Neue Ephemeropteren. Archiv für Naturgeschichte, Abteilung A, 85 (11), 1-80. 